\title{
Association of vitamin $D$ receptor polymorphisms with the risk of prostate cancer in the Han population of Southern China
} Yongheng $\mathrm{Bai}^{\dagger 1}$, Yaping $\mathrm{Yu}^{\dagger 2}$, Bin $\mathrm{Yu}^{2}$, Jianrong $\mathrm{Ge}^{2}$, Jingzhang $\mathrm{Ji}^{4}$, Hong $\mathrm{Lu}^{3}$, Jia Wei ${ }^{1}$, Zhiliang Weng ${ }^{1}$, Zhihua Tao ${ }^{3}$ and Jianxin $\mathrm{Lu}^{* 1}$

Address: ${ }^{1}$ Zhejiang Provincial Key Laboratory of Medical Genetics, School of Laboratory Medicine and Life Science, Wenzhou Medical College, Wenzhou 325035, PR China, ${ }^{2}$ Medical College of Shaoxing University, Shaoxing 312000, PR China, ${ }^{3}$ Laboratory Diagnostic Center of the First Affiliated Hospital of Wenzhou Medical College, Wenzhou 325000, PR China and ${ }^{4}$ Department of Urology of the First Affiliated Hospital of Wenzhou Medical College, Wenzhou 325000, PR China

Email: Yongheng Bai - greatsailor@163.com; Yaping Yu - yypyyp1953@163.com; Bin Yu - yubinshow@163.com; Jianrong Ge-GJR@zscas.edu.cn; Jingzhang Ji - jingzhangji@gmail.com; Hong Lu - luhonglisa@hotmail.com; Jia Wei - weijia1983@163.com; Zhiliang Weng - wengzl2001@163.com; Zhihua Tao - wwwtzh@mail.wzptt.zj.cn; Jianxin Lu* - jxlu313@gmail.com

* Corresponding author †Equal contributors

Published: 4 December 2009

BMC Medical Genetics 2009, 10:125 doi:10.1/86/147/-2350-10-125
Received: 8 April 2009

Accepted: 4 December 2009

This article is available from: http://www.biomedcentral.com//47I-2350//0//25

(c) 2009 Bai et al; licensee BioMed Central Ltd.

This is an Open Access article distributed under the terms of the Creative Commons Attribution License (http://creativecommons.org/licenses/by/2.0), which permits unrestricted use, distribution, and reproduction in any medium, provided the original work is properly cited.

\begin{abstract}
Background: Molecular epidemiological studies have shown that gene polymorphisms of vitamin $D$ receptor (VDR) are associated with prostate cancer risks. However, previous results from many molecular studies remain inconsistent.
\end{abstract}

Methods: Blood samples were collected from 122 prostate cancer patients and I 30 age-matched control subjects in the Han population of Southern China. The differences of VDR gene polymorphism between cancer cases and controls were determined by PCR-RFLP, examiming Fokl (exon 2), Bsml, Tru9l, Apal (intron 9), and Taql (exon 9). Associations between the VDR gene polymorphism and prostate cancer risk were calculated in an unconditional logistic regression model. Linkage disequilibrium and haplotypes were analyzed with the SHEsis software.

Results: Of five polymorphisms, Bsml was shown to associate with prostate cancer, while Fokl, Tru9l, Apal, and Taql did not show any significant association. After adjustment for age, the Bsml 'B' allele was associated with an almost $1 / 3$-fold risk $(O R=0.35,95 \% \mathrm{Cl}: 0.15-0.80)$ of the occurrence of prostate cancer, a $\mathrm{I} / 5$-fold risk $(\mathrm{OR}=0.20,95 \% \mathrm{Cl}$ : $0.06-0.68)$ of poorly differentiated prostate cancer, and a I/I0-fold risk (OR $=0.10,95 \% \mathrm{Cl}: 0.0 \mathrm{I}-0.78)$ of aggressive prostate cancer compared with the ' $b$ ' allele, especially among older men ( $>7$ I years). In addition, haplotype analysis revealed that the ' $F-b-U-A-T$ ' was more frequent found in cases than in controls $(3.4 \%$ vs $0.0 \%, P=0.0035)$, while the frequency of haplotype ' $F-B-U-a-T$ ' was $0.8 \%$ in cases, significantly lower than in controls $(3.9 \%, P=0.019)$.

Conclusion: Our experiments provide evidences that genetic polymorphisms in the VDR gene may be potential risk factors for prostate cancer in the Han population of southern China and the susceptibility to prostate cancer is associated with ethnicity and geographic location. 


\section{Background}

Prostate cancer is the most common type of tumor in old men throughout the world. In 2003, about 220,900 new cases of prostate cancer were diagnosed in the United States [1]. Although epidemiological studies showed that the incidence of prostate cancer in Asians is much lower than that in African-Americans [2], the occurrence of this disease has rapidly increased among Chinese men [3]. In the Shanghai population, the incidence was $1.9 / 10$ million in 1983, but it increased to 21.08/10 million in 2005 [4]. The incidence rate in Beijing was similar to that of Shanghai [5]. Age, race, and geographical factors are wellestablished risk factors of prostate cancer [6]. However, these factors may not completely explain the differences between different ethnic groups in prostate cancer rates. Therefore, genetic variation in certain genes, including genes controlling vitamin $\mathrm{D}$ activity, could play a role in determination of susceptibility to prostate cancer.

Based on investigations of the differences in prostate cancer incidence at different latitudes in the United States, Schwartz et al. $[7,8]$ hypothesized that low ultraviolet exposure may be a risk factor for prostate cancer. After exposure to UV radiation, vitamin $\mathrm{D}$ is produced in the skin and then hydroxylated in the liver to 25-hydroxyvita- min $\mathrm{D}_{3}$, and in the kidneys to the more physiologically

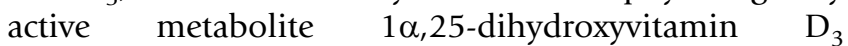
$\left[1,25(\mathrm{OH})_{2} \mathrm{D}_{3}\right]$. The biological activity of $1,25(\mathrm{OH})_{2} \mathrm{D}_{3}$ is mediated primarily by vitamin $\mathrm{D}$ receptor (VDR). In addition to kidney and bone cells, VDR [9] is also expressed in human prostatic cells, and a series of experiments revealed that VDR mediates the influence of $1,25(\mathrm{OH})_{2} \mathrm{D}_{3}$ on the growth, differentiation $[10,11]$, and apoptosis [12] of prostatic cells. These findings indicated that $1,25(\mathrm{OH})_{2} \mathrm{D}_{3}$ and its specific nuclear receptor protein, VDR, may be closely associated with prostate cancer risk.

The expression and function of VDR may be influenced by $V D R$ gene polymorphisms. Polymorphisms (intron 8, exon 9, and polyA microsatellite, Figure 1) in the 3' end may correlate with gene transcription [13]. In exon 2 of $5^{\prime}$ end, the FokI $F$ allele may lack the first start codon [14], resulting in a VDR protein that is shortened by three amino acids [15]. This protein variant was shown to be more efficient at transactivating a vitamin D-regulated target gene [16]. Polymorphic variants of the VDR gene have been suggested to be associated with prostate cancer risk and/or a more aggressive phenotype $[17,18]$. Gene polymorphisms have been reported to be of significant relevance with cancer risk in many different populations [17-

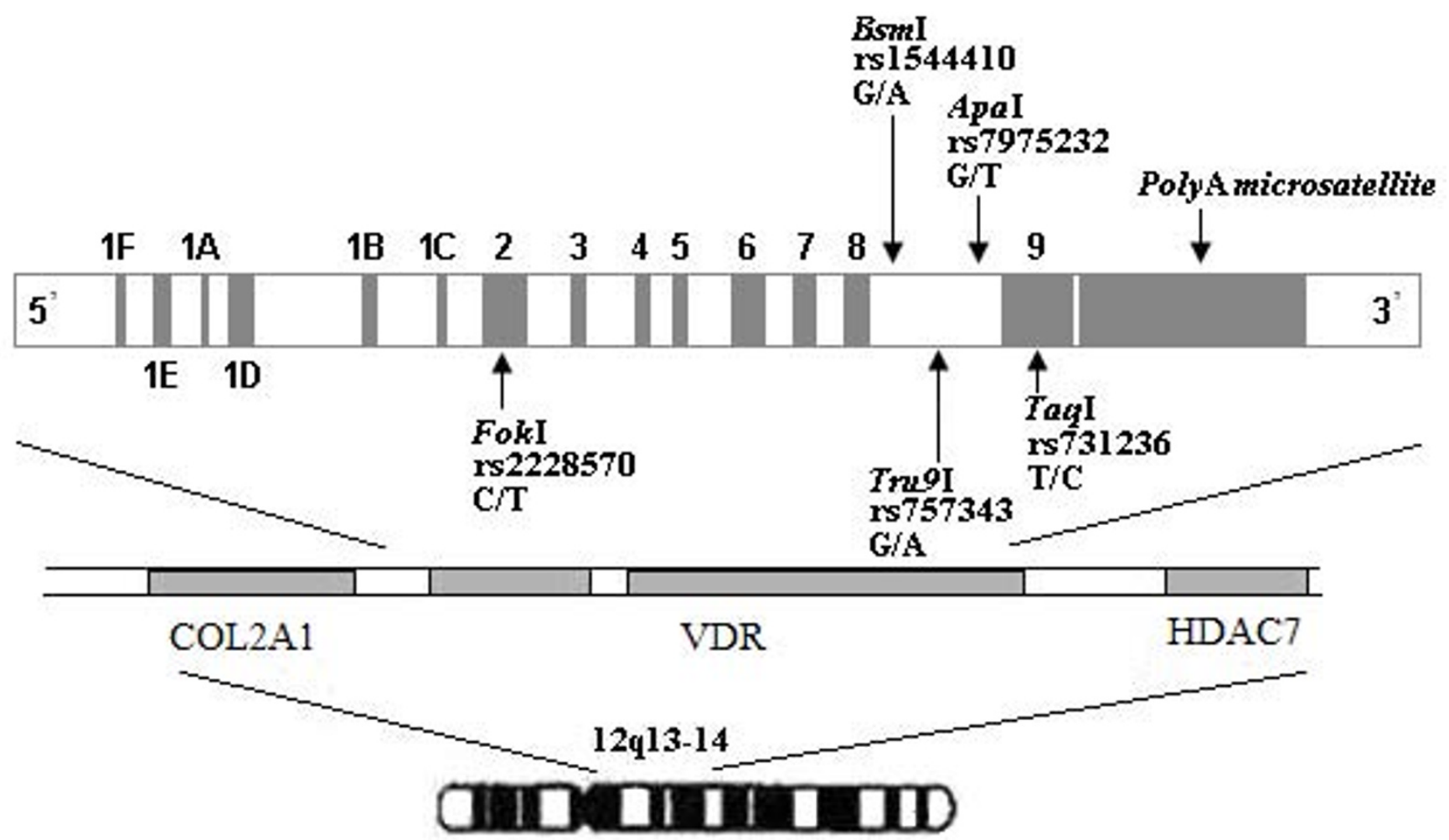

Figure I

Positions of polymorphisms in the vitamin D receptor gene. 
26]. Since there is a series of VDR gene polymorphisms that are in strong linkage disequilibrium with one another, some VDR haplotypes have also been reported to be linked with prostate cancer $[27,28]$. However, other studies [29-33] did not show such significant associations. The inconsistent results were probably due to differences in the study populations $[20,22]$.

In this report, we carried out a population-based, casecontrol study to evaluate the association between VDR gene polymorphisms and prostate cancer risk in the Han population of Southern China because one salient characteristic of China's population has a large base with diverse genetic backgrounds. The present study can provide a platform to help explain the pathological mechanism of prostate cancer and to a better understanding of the geographic and ethnic differences associated with disease incidence and mortality.

\section{Methods}

\section{Subjects}

In the present study, 122 prostate cancer patients and 130 age-matched male controls were enrolled in four hospitals in southern China between March 2007 and August 2008. All prostate cancer cases were confirmed by pathological examination. The pathologic grades were classified according to the Gleason score as well and moderately differentiated (Gleason 2-6) and poorly differentiated (Gleason 7-10) [34]. Based on the TNM classification system promulgated by the American Joint Committee on Cancer, the disease stage was divided into localized and aggressive cancer, as determined by transrectal ultrasound, magnetic resonance imaging (MRI) and emission computed tomography (ECT). Localized prostate cancer can be detectable clinically or felt (palpated) on examination, but has not spread outside the prostate. Aggressive cancer means the cancer has spread through the prostatic capsule (eg, bladder neck, external sphincter, rectum, and levator muscles) and even has invaded other nearby structures (eg, bone and pancreas).
The age-matched control subjects were individuals recruited from retired employees at the First Affiliated Hospital of Wenzhou Medical College. The controls were screened to ensure that there had never been diagnosed with cancer and had low plasma prostate-specific antigen (PSA) levels (total PSA $<4.00 \mathrm{ng} / \mathrm{ml}$ ). The controls were also checked for cancer history based on their past medical records and/or asked directly for their cancer history.

All subjects were informed about the contents of the study and gave their informed consent. This study was approved by the Ethics Committee of Wenzhou Medical College.

\section{Molecular analysis}

Blood samples were collected with the anticoagulant EDTA $\mathrm{K}_{2}$ and stored at $-20^{\circ} \mathrm{C}$. Genomic DNA was extracted using a DNA Extraction Kit (TaKaRa Bio Group, Japan) and stored at $4^{\circ} \mathrm{C}$. VDR polymorphisms were genotyped by PCR-RFLP and the condition was displayed in the Table 1 . To control the experiments, a total of $80 \mathrm{sam}$ ples were randomly selected and genotyped and confirmed by DNA sequencing by a second investigator.

FokI, BsmI, Tru9I, ApaI, and TaqI, are reported according to the standard nomenclature in which lowercase and uppercase letters indicate the presence or absence of a restriction site, respectively. The FokI $T$ and $C$ alleles are represented by $f$ and $F$, the BsmI $G$ and $A$ alleles by $b$ and $B$, the Tru9I $G$ and $A$ alleles by $U$ and $u$, the ApaI $T$ and $G$ alleles by $A$ and $a$, and the TaqI $T$ and $C$ alleles by $T$ and $t$, respectively.

\section{Statistical analysis}

Tests for Hardy-Weinberg equilibrium were performed separately for each SNP among case and control subjects. The Independent-Samples $\mathrm{T}$ test was used to determine differences according to age, and the chi-square or Fisher's exact test was performed to calculate the clinical parametric distributions. Unconditional logistic regression analysis models were used to evaluate the relationships between different genotypes and disease risk [Odds ratios

Table I: PCR-RFLP conditions for VDR gene polymorphisms (GenBank AY34240I)

\begin{tabular}{|c|c|c|c|c|}
\hline SNP & Primer & Base change & Annealing temperature & Restriction enzyme \\
\hline \multirow[t]{2}{*}{ Fokl } & 5'AGCTGGCCCTGGCACTGACTCTGCTCT3'(F) & $\mathrm{C} / \mathrm{T}$ & $61^{\circ} \mathrm{C}$ & Fok I \\
\hline & 5'ATGGAAACACCTTGCTTCTTCTCCCTC 3'(R) & & & \\
\hline \multirow[t]{2}{*}{ Bsml } & 5'CAACCAAGACTACAAGTACCGCGTCAGTGA3'(F) & $\mathrm{G} / \mathrm{A}$ & $57^{\circ} \mathrm{C}$ & Mval269I \\
\hline & 5'AACCAGCGGGAAGAGGTCAAGGG3'(R) & & & \\
\hline \multirow[t]{2}{*}{ Tru9l } & 5'CAACCAAGACTACAAGTACCGCGTCAGTGA3'(F) & $\mathrm{G} / \mathrm{A}$ & $57^{\circ} \mathrm{C}$ & Trul I \\
\hline & 5'AACCAGCGGGAAGAGGTC AAGGG3'(R) & & & \\
\hline \multirow[t]{2}{*}{ Apal } & 5'CAGAGCATGGACAGGGAGCAA3'(F) & $\mathrm{G} / \mathrm{T}$ & $60^{\circ} \mathrm{C}$ & Apa I \\
\hline & 5'GCAACTCCTCATGGCTGAGGTCTC3'(R) & & & \\
\hline \multirow[t]{2}{*}{ Taql } & 5'CAGAGCATGGACAGGGAGCAA3'(F) & $\mathrm{T} / \mathrm{C}$ & $60^{\circ} \mathrm{C}$ & Taq I \\
\hline & 5'GCAACTCCTCATGGCTGAGGTCTC3'(R) & & & \\
\hline
\end{tabular}


(OR), 95\% confidence intervals (95\% CI)] adjusted by age. Linkage disequilibrium and haplotypes were analyzed with the SHEsis software [35]. A p-value of less than 0.05 was considered as statistically significant.

\section{Results and Discussion}

The worldwide incidence of clinical prostate cancer shows a strong dependence on age, race, and geography. For example the incidence in African-Americans was significantly higher than that in Asians, especially in the Chinese population. Recent epidemiological studies in different populations have indicated that difference in VDR genotype frequencies may play an important role in the risk of prostate cancer. In the present study, we evaluated the association between five polymorphisms in the VDR gene and prostate cancer risk in the southern Chinese Han population.

Table 2 shows the demographic and clinical characteristics of the subjects (122 prostate cancer patients and 130 non-cancer controls). No significant differences in age, smoking status, or alcohol intake were observed between cases and controls. In the present study, five polymorphisms, including FokI at the $5^{\prime}$ end of exon 2, and BsmI, Tru9I, ApaI, and TaqI in the 3'UTR region, were evaluated, and each SNP was in Hardy-Weinberg equilibrium. Statistical analysis revealed a significant difference in the allelic frequencies of the BsmI genotype (Table 3), while other polymorphisms did not show any significant differences. Compared with $B s m I$ ' $b b^{\prime}$, subjects with ' $B B^{\prime}$ ' and ' $B b$ ' genotypes were associated with a decreased risk $(\mathrm{OR}=0.35$, 95\%CI: $0.15-0.81, P=0.015)$. The BsmI ' $B$ ' allelic frequency was $3.7 \%$ in cancer patients, which was significantly lower than that of controls $(8.5 \%)$, indicating a decreased disease risk associated with this allele $(\mathrm{OR}=$ $0.35,95 \% \mathrm{CI}$ : $0.15-0.80, P=0.013)$. To evaluate the association modified by the age, we stratified the age to two groups ( $>71$ and $\leqq 71$ years). Among the elderly men, the OR value for the " $B$ " allele was 0.09 (95\%CI: 0.01-0.68) versus the " $b$ " allele (Table 4 ), and the OR value was 0.64 (95\%CI: 0.25-1.66) among the younger men, suggesting that the elder men with the " $B$ " allele had lower risk of prostate cancer. In addition, when stratifying our material according to Gleason score and TNM classification, a number of significant results were found. The ' $B$ ' allele (compared to the ' $b$ ' allele) was also associated with a decreased risk of aggressive $(\mathrm{OR}=0.10,95 \% \mathrm{CI}$ : 0.01-0.78, $P=0.028)$ and poorly differentiated cancer $(\mathrm{OR}=0.20$, 95\%CI: 0.06-0.68, $P=0.010$, Table 4). Considering the number of cases with the variant allele for most of these strata is too small, and future research needs to further expand the sample size to confirm these results.

Based on observations of the distribution difference between prostate cancer cases and controls, we here hypothesize the BsmI 'B' allele might have a protective effect against tumorigenesis. Previous studies also found that the $\mathrm{BsmI}$ ' $\mathrm{BB}+\mathrm{Bb}$ ' genotype was associated with onethird the risk of prostate cancer in a Japanese population [20] and one-fifth the risk in advanced stages and in poorly differentiated disease in a Taiwanese population [36]. Although Ma et al. [37] reported no significant association between the BsmI polymorphism and prostate cancer risk, they did find a 57\% reduction in the risk of prostate cancer with the BsmI 'BB' genotype compared with the 'bb' genotype in American men. These data also support our findings concerning the protective effect of the BsmI ' $\mathrm{B}$ ' allele. However, there are still some studies

Table 2: Clinic and demographic characteristics of the subjects

\begin{tabular}{|c|c|c|c|c|}
\hline & Cases $(n=122)$ & Controls $(n=130)$ & OR(95\%Cl) & $P$ value \\
\hline Ages at diagnosis (year) ${ }^{\mathrm{a}}$ & $71.77 \pm 8.12$ & $71.28 \pm 7.86$ & & 0.632 \\
\hline$<60$ & II (9.0\%) & II (8.5\%) & & \\
\hline $60 \sim 69$ & $33(27.1 \%)$ & $42(32.3 \%)$ & & \\
\hline $70 \sim 79$ & $56(45.9 \%)$ & $59(45.4 \%)$ & & \\
\hline$\geq 80$ & $22(18.0 \%)$ & $18(13.8 \%)$ & & \\
\hline \multicolumn{5}{|l|}{ Smoking status ${ }^{b}$} \\
\hline Nonsmoking & $82(67.2 \%)$ & $91(70.0 \%)$ & $1.138(0.668-1.939)$ & 0.634 \\
\hline Smoking & $40(32.8 \%)$ & $39(30.0 \%)$ & & \\
\hline \multicolumn{5}{|l|}{ Alcohol intake b } \\
\hline No alcohol & $62(50.8 \%)$ & $69(53.1 \%)$ & $1.095(0.668-1.795)$ & 0.720 \\
\hline Drinking & $60(49.2 \%)$ & $61(46.9 \%)$ & & \\
\hline \multicolumn{5}{|l|}{ Gleason score } \\
\hline$<7$ & $43(35.2 \%)$ & & & \\
\hline$\geq 7$ & $79(64.8 \%)$ & & & \\
\hline \multicolumn{5}{|l|}{ TNM classification } \\
\hline Localized & 72 (59.0\%) & & & \\
\hline Aggressive & 50 (4I.0\%) & & & \\
\hline
\end{tabular}

a, Data are expressed as mean \pm standard deviation (SD), $P$ values are calculated using unpaired $t$-test;

b, Based on chi-square test. 
Table 3: Distribution of VDR genotypes and alleles between prostate cancer cases and controls

\begin{tabular}{|c|c|c|c|c|c|}
\hline & & Cases (freq) & Controls (freq) & OR(95\%Cl) & $P$ value \\
\hline \multirow[t]{5}{*}{ Fokl } & FF & $33(0.270)$ & $38(0.292)$ & 1.00 (referent) & \\
\hline & $\mathrm{Ff}$ & $63(0.517)$ & $55(0.423)$ & $1.317(0.730-2.376)$ & 0.361 \\
\hline & ff & $26(0.213)$ & $37(0.285)$ & $0.815(0.4 \mid I-1.620)$ & 0.560 \\
\hline & $F$ & $129(0.529)$ & $131(0.504)$ & 1.00 (referent) & \\
\hline & $f$ & $115(0.47 I)$ & $129(0.496)$ & $0.910(0.64|-| .29 \mid)$ & 0.597 \\
\hline \multirow[t]{5}{*}{ Bsml } & $b b$ & $\mathrm{I} 14(0.934)$ & $108(0.831)$ & 1.00 (referent) & \\
\hline & $B b$ & $8(0.066)$ & $21(0.162)$ & $0.362(0.154-0.853)$ & 0.020 \\
\hline & $B B *$ & $0(0)$ & I $(0.008)$ & - & - \\
\hline & $b$ & $236(0.964)$ & $237(0.912)$ & 1.00 (referent) & \\
\hline & B & $8(0.036)$ & $23(0.088)$ & $0.35 I(0.154-0.800)$ & 0.013 \\
\hline \multirow[t]{5}{*}{ Tru9l } & UU & $76(0.623)$ & $78(0.600)$ & 1.00 (referent) & \\
\hline & $U u$ & $41(0.336)$ & $47(0.362)$ & $0.902(0.533-1.525)$ & 0.699 \\
\hline & uu & $5(0.04 I)$ & $5(0.038)$ & $1.039(0.289-3.742)$ & 0.953 \\
\hline & $U$ & $193(0.791)$ & $203(0.781)$ & 1.00 (referent) & \\
\hline & $u$ & $51(0.209)$ & $57(0.219)$ & $0.947(0.6 \mid 8-1.452)$ & 0.804 \\
\hline \multirow[t]{5}{*}{ Apal } & $A A$ & $10(0.082)$ & $9(0.069)$ & 1.00 (referent) & \\
\hline & $\mathrm{Aa}$ & $56(0.459)$ & $61(0.469)$ & $0.800(0.300-2.128)$ & 0.654 \\
\hline & $a a$ & $56(0.459)$ & $60(0.462)$ & $0.810(0.304-2.160)$ & 0.673 \\
\hline & $A$ & $76(0.311)$ & $79(0.304)$ & 1.00 (referent) & \\
\hline & $a$ & $168(0.689)$ & $181(0.696)$ & $0.956(0.654-1.397)$ & 0.814 \\
\hline \multirow[t]{5}{*}{ Taql } & $T T$ & $112(0.918)$ & $121(0.931)$ & $\mathrm{I} .00$ (referent) & \\
\hline & $T t$ & $10(0.082)$ & $9(0.069)$ & $1.213(0.475-3.098)$ & 0.687 \\
\hline & $t t$ & $0(0)$ & $0(0)$ & - & - \\
\hline & $T$ & $234(0.959)$ & $251(0.965)$ & 1.00 (referent) & \\
\hline & $t$ & $10(0.041)$ & $9(0.035)$ & $1.204(0.480-3.016)$ & 0.693 \\
\hline
\end{tabular}

$*$, Genotype $(B B+B b)$ vs $b b, \mathrm{OR}_{\text {age-adjusted }}=0.346,95 \% \mathrm{Cl}: 0.148-0.8 \mathrm{II}, P=0.015$.

failed to show such a result. For example, studies such as Liu et al. [32] in Beijing population and Ingles et al. [28] in African-Americans. In addition to ethnic characteristics, geographical differences and living habits, the factors, including the study sample size, the choice of the control group (BPH or healthy people), might be the important reasons for these inconsistent results.

Although the BsmI polymorphic variant is in the untranslated intron 8 and does not seem to alter the VDR amino acid sequence, some studies have reported that the BsmI ' $B B$ ' genotype is significantly associated with higher plasma $1,25(\mathrm{OH}){ }_{2} \mathrm{D}_{3}\left(\right.$ median $=36.2 \mathrm{pg} / \mathrm{ml}$ for the ' $B B^{\prime}$ versus $33.9 \mathrm{pg} / \mathrm{ml}$ for the ' $b b$ ' genotype; $P=0.02)$, suggesting that the BsmI polymorphic variant is associated with VDR function [37]. In fact, strong linkage disequilibrium was detected among four polymorphisms, including Bsm I in the 3'UTR region (Table 5), which is consistent with other studies [13,18,36,38]. In addition, the effect of BsmI may be influenced by other polymorphisms.

Haplotypes with five-locus (FokI, BsmI, Tru9I, ApaI, and TaqI) of VDR gene polymorphisms were also analyzed with SHEsis software. We found that the haplotype ' $F-b-U$ -

Table 4: Age-adjusted ORs and $P$ value in different kinds of patients compared with controls by Bsml polymorphisms

\begin{tabular}{|c|c|c|c|c|c|c|c|c|c|c|c|c|c|}
\hline & \multirow[b]{2}{*}{ Controls } & \multicolumn{4}{|c|}{ Pathological grade } & \multicolumn{4}{|c|}{ Clinic stage } & \multicolumn{4}{|c|}{ Age stratification (years)* } \\
\hline & & $\begin{array}{l}\text { Well- } \\
\text { mod }\end{array}$ & $\begin{array}{c}\text { OR } \\
(95 \% \mathrm{Cl})\end{array}$ & Poorly & $\begin{array}{c}\text { OR } \\
(95 \% \mathrm{Cl})\end{array}$ & Localized & $\begin{array}{c}\text { OR } \\
(95 \% \mathrm{Cl})\end{array}$ & Aggressive & $\begin{array}{c}\text { OR } \\
(95 \% \mathrm{Cl})\end{array}$ & $>71$ & $\begin{array}{c}\text { OR } \\
(95 \% \mathrm{Cl})\end{array}$ & $\leqq 7 \mathbf{I}$ & $\begin{array}{c}\text { OR } \\
(95 \% \mathrm{Cl})\end{array}$ \\
\hline$b b$ & 108 & 38 & $\begin{array}{c}1.00 \\
\text { (referent) }\end{array}$ & 76 & $\begin{array}{c}1.00 \\
\text { (referent) }\end{array}$ & 65 & $\begin{array}{c}1.00 \\
\text { (referent) }\end{array}$ & 49 & $\begin{array}{c}1.00 \\
\text { (referent) }\end{array}$ & 62 & $\begin{array}{c}1.00 \\
\text { (referent) }\end{array}$ & 52 & $\begin{array}{c}1.00 \\
\text { (referent) }\end{array}$ \\
\hline$B b$ & 21 & 5 & $\begin{array}{c}I .44 \\
(0.5 I-4.1 I)\end{array}$ & 3 & $\begin{array}{c}0.20 \\
(0.06-0.71)\end{array}$ & 7 & $\begin{array}{c}0.56 \\
(0.23-1.40)\end{array}$ & 1 & $\begin{array}{c}0.11 \\
(0.01-0.81)\end{array}$ & 1 & $\begin{array}{c}0.08 \\
(0.01-0.64)\end{array}$ & 7 & $\begin{array}{c}0.73 \\
(0.26-2.04)\end{array}$ \\
\hline$B B$ & 1 & 0 & & 0 & & 0 & & 0 & & 0 & & 0 & \\
\hline$B b+B B$ & 22 & 5 & $\begin{array}{c}0.97 \\
(0.93-1.02)\end{array}$ & 3 & $\begin{array}{c}0.19 \\
(0.06-0.67)\end{array}$ & 7 & $\begin{array}{c}0.54 \\
(0.22-1.33)\end{array}$ & 1 & $\begin{array}{c}0.10 \\
(0.01-0.77)\end{array}$ & 1 & $\begin{array}{c}0.08 \\
(0.01-0.64)\end{array}$ & 7 & $\begin{array}{c}0.67 \\
(0.25-1.85)\end{array}$ \\
\hline$b$ & 237 & 81 & $\begin{array}{l}1.00 \\
\text { (referent) }\end{array}$ & 155 & $\begin{array}{c}1.00 \\
\text { (referent) }\end{array}$ & 137 & $\begin{array}{l}1.00 \\
\text { (referent) }\end{array}$ & 99 & $\begin{array}{l}1.00 \\
\text { (referent) }\end{array}$ & 125 & $\begin{array}{c}1.00 \\
\text { (referent) }\end{array}$ & 109 & $\begin{array}{l}1.00 \\
\text { (referent) }\end{array}$ \\
\hline B & 23 & 5 & $\begin{array}{c}0.97 \\
(0.94-1.00)\end{array}$ & 3 & $\begin{array}{c}0.20 \\
(0.06-0.68)\end{array}$ & 7 & $\begin{array}{c}0.53 \\
(0.22-1.28)\end{array}$ & 1 & $\begin{array}{c}0.10 \\
(0.01-0.78)\end{array}$ & 1 & $\begin{array}{c}0.09 \\
(0.01-0.68)\end{array}$ & 7 & $\begin{array}{c}0.64 \\
(0.25-1.66)\end{array}$ \\
\hline
\end{tabular}

*, Stratified by the average age of 71 years. 
Table 5: Linkage disequilibrium test between five VDR gene polymorphisms

\begin{tabular}{|c|c|c|c|c|}
\hline SNPI & SNP2 & Distance between two polymorphisms & D' & $P$ value $^{a}$ \\
\hline Fokl & Bsml & 33060 & 0.513 & 0.110 \\
\hline Fokl & Tru9l & 33220 & 0.096 & 0.803 \\
\hline Fokl & Apal & 34058 & 0.169 & 0.379 \\
\hline Fokl & Taql & 34138 & 0.299 & 0.739 \\
\hline Bsml & Tru9l & 160 & 0.574 & 0.253 \\
\hline Bsml & Apal & 998 & 0.556 & 0.006 \\
\hline Bsml & Taql & 1078 & 0.826 & $<0.001$ \\
\hline Tru9l & Apal & 838 & 0.831 & $<0.001$ \\
\hline Tru91 & Taql & 918 & 0.953 & $<0.001$ \\
\hline Apal & Taql & 80 & 0.900 & $<0.001$ \\
\hline
\end{tabular}

a, Based on chi-square test.

$A-T^{\prime}$ was more frequent in cases than in controls $(3.4 \% v s$. $0.0 \%, P=0.0035$; Table 6 ), while the frequency of haplotype ' $F-B-U-a-T$ ' was $0.8 \%$ in cases, significantly lower than that in controls $(3.9 \%, P=0.019)$, indicating that the haplotype ' $F-b-U-A-T$ ' was associated with increased risk of prostate cancer and the 'F-B-U-a-T' with a decreased risk. In Caucasian and African-Americans, an association was observed between disease risk and the four-locus ' $F$ - $B$ $A-t$ ' haplotype (OR $=0.48,95 \% \mathrm{CI}$ : 0.30-0.76) compared with the ' $F-b-a-T$ ' haplotype, as reported by Cicek et al. [27]. The haplotype results obtained in that study also partly support our conclusion. In addition to BsmI, linkage disequilibrium data also showed that other polymorphisms (Tru9I, ApaI, and TaqI) may play some role in disease risk through their interactions. Taylor et al. [17] reported that the $T a q \mathrm{I}$ ' $t t$ ' genotype is significantly decreased in prostate cancer patients $(8 \%)$ compared to noncancer controls in Caucasian Americans (22\%; OR = 0.32; 95\%CI: 0.15-0.75). A study of a southern European population also showed an association of the TaqI 'T 'allele with cancer risk [22]. However, our study showed that these polymorphisms demonstrated no significant differences in the southern Chinese Han population, which also suggested that the distribution of VDR gene polymorphisms may be associated with ethnicity and/or location.

The distribution of polymorphisms in the 3'UTR region of the VDR gene may be relavant with VDR mRNA stability and gene transcription [13]. Alterations in the ability of VDR protein to bind $1,25(\mathrm{OH})_{2} \mathrm{D}_{3}$ or activate the VDRE gene would ultimately result in changes in the expression of regulatory genes, such as $C D K$, which can directly or indirectly control prostatic cell division. If the protective

Table 6: Haplotype frequencies for VDR five polymorphisms between prostate cancer cases and controls

\begin{tabular}{|c|c|c|c|c|}
\hline Haplotypes & Controls (freq) & Cases (freq) & $P$ value ${ }^{a}$ & OR (95\%Cl) \\
\hline$F-b-U-A-T$ & $0.00(0.000)$ & $8.90(0.034)$ & 0.0035 & - \\
\hline$F-b-U-a-t$ & $6.98(0.029)$ & $5.29(0.020)$ & - & - \\
\hline$F-b-U-a-T$ & $0.00(0.000)$ & $1.94(0.007)$ & - & - \\
\hline F-B-u-A-T & $6.31(0.026)$ & $4.31(0.017)$ & - & - \\
\hline$F-B-u-a-T$ & 18.06(0.074) & 17.75(0.068) & 0.806 & $0.92(0.46 \sim 1.82)$ \\
\hline$F-B-U-A-T$ & $87.01(0.357)$ & $90.69(0.349)$ & 0.863 & $0.97(0.67 \sim 1.4 \mathrm{I})$ \\
\hline$F-B-U-a-T$ & $9.56(0.039)$ & $2.03(0.008)$ & 0.019 & $0.19(0.04 \sim 0.89)$ \\
\hline$f-B-u-a-T$ & $0.00(0.000)$ & $1.65(0.006)$ & - & - \\
\hline$f-B-U-a-t$ & $0.00(0.000)$ & $2.66(0.010)$ & - & - \\
\hline$f-b-U-a-T$ & $0.00(0.000)$ & $2.48(0.010)$ & - & - \\
\hline$f-B-u-A-T$ & $1.54(0.006)$ & $0.00(0.000)$ & - & - \\
\hline$f-B-u-a-T$ & $25.09(0.103)$ & $33.21(0.128)$ & 0.376 & $1.28(0.74 \sim 2.23)$ \\
\hline$f-B-U-A-T$ & $72.11(0.296)$ & $77.10(0.297)$ & 0.970 & $1.01(0.68 \sim 1.49)$ \\
\hline$f-B-U-a-t$ & $1.00(0.004)$ & $1.05(0.004)$ & - & - \\
\hline$f-B-U-a-T$ & 14.32(0.059) & $10.86(0.042)$ & 0.385 & $0.70(0.31 \sim 1.57)$ \\
\hline$F-B-U-a-t$ & $1.00(0.004)$ & $0.00(0.000)$ & - & - \\
\hline$f-b-U-A-t$ & $0.92(0.004)$ & $0.00(0.000)$ & - & - \\
\hline$f-B-u-A-T$ & I.54(0.006) & $0.00(0.000)$ & - & - \\
\hline
\end{tabular}

a, Based on Fisher's exact test;

All those frequency $<0.10$ will be ignored in analysis. 
action of the BsmI ' $B$ ' allele is confirmed experimentally, the pathological mechanism of prostate cancer would be better understand. In addition, we observed the genotype and allelic frequencies of $V D R$ gene varied from race to race. For example, the allelic frequency of TaqI ' $T$ ' in the southern Chinese Han population $(96.5 \%$, in control) was significantly higher than that in white Americans (55.2\%) [17] and Portuguese (57.8\%) [22]. Thus, the distribution of $V D R$ gene polymorphisms may help explain the difference in incidence of prostate cancer in different populations.

\section{Conclusion}

In conclusion, the present study indicated that $V D R$ gene polymorphisms may be associated with prostate cancer risk in the southern Chinese Han population, and these associations may largely depend on population characteristics and geographic location.

\section{Abbreviations}

All abbreviations are defined in the text.

\section{Competing interests}

The authors declare that they have no competing interests.

\section{Authors' contributions}

YHB, YPY and JXL conceived the study, designed and coordinated it, performed part of the molecular genetic studies, data analysis, and wrote the manuscript. WJ participated in the molecular genetic studies. BY, JRG, JZJ, $\mathrm{HL}$, ZLW and ZHT participated in the recruitment of prostate cancer cases and control subjects. All authors read and approved the final manuscript.

\section{Acknowledgements}

We thank Dr. Luhu Shan (Zhejiang Cancer Hospital) and Dr. Guiqin Sun (Shaoxing People's Hospital) for their contributions to the subject assistance. This study was sponsored by Zhejiang Provincial Program for the Cultivation of High-level Innovative Health talents and Zhejiang Provincial Top Key Discipline of Laboratory Medicine, and supported by the Shaoxing Scientific Planning Key Project (Grant 2006A230 I4).

\section{References}

I. American Cancer Society: Cancer Facts and Figures 2003 [http:// www.cancer.org/docroot/home/index.asp].

2. Quinn M, Babb P: Patterns and trends in prostate cancer incidence, survival, prevalence and mortality. Part I: international comparisons. BJU Int 2002, 90:162-173.

3. Ostrander EA, Stanford JL: Genetics of prostate cancer: too many loci, too few genes. Am J Hum Genet 2000, 67: I367-I375.

4. The incidence of cancer in Shanghai city in 1983-2005. Tumor 2008, 28:571.

5. Gu FL: Changing constituents of genitourinary cancer in recent 50 years in Beijing. Chin Med J (Eng l) 2003, I 16:1391-1393.

6. Zhang HF, Wang HL, Xu N, Li SW, Ji GY, Li XM, Pang YZ, Zhang L, Zhao XJ, Gao HW: Mass screening of 12027 elderly men for prostate carcinoma by measuring serum prostate specific antigen. Chin Med J (Eng I) 2004, I I 7:67-70.
7. Schwartz GG, Hulka BS: Is vitamin D deficiency a risk factor for prostate cancer? (hypothesis). Anticancer Res 1990, 10:1307-|3|I.

8. Hanchette CL, Schwartz GG: Geographic patterns of prostate cancer mortality: evidence for a protective effect of ultraviolet radiation. Cancer (Phila.) 1992, 70:286I-2869.

9. Miller GJ, Stapleton GE, Ferrara JA, Lucia MS, Pfister S, Hedlund TE, Upadhya $P$ : The human prostatic carcinoma cell line LNCaP expresses biologically active, specific receptors for Ia,25 dihydroxyvitamin D3. Cancer Res 1992, 52:5I5-520.

10. Peehl DM, Skowronski RJ, Leung GK, Wong ST, Stamey TA, Feldman $D$ : Antiproliferative effects of I,25-dihydroxyvitamin D3 on primary cultures of human prostatic cells. Cancer Res 1994, 54:805-8I0

II. Schwartz GG, Wang MH, Zang M, Singh RK, Siegal GP: Ia,25-Dihydroxyvitamin $D$ (calcitriol) inhibits the invasiveness of human prostate cancer cells. Cancer Epidemiol Biomarkers Prev 1997, 6:727-732.

12. Guzey M, Kitada S, Reed JC: Apoptosis induction by Ialpha, 25dihydroxyvitamin D3 in prostate cancer. Mol Cancer Ther 2002, I:667-677.

13. Morrison NA, Qi JC, Tokita A, Kelly PJ, Crofts L, Nguyen TV, Sambrook PN, Eisman JA: Prediction of bone density from vitamin D receptor alleles. Nature 1994, 367:284-287.

14. Saijo T, Ito M, Takeda E, Huq AH, Naito E, Yokota I, Sone T, Pike JW, Kuroda $Y$ : $A$ unique mutation in the vitamin $D$ receptor gene in three Japanese patients with vitamin D-dependent rickets type II: utility of single-strand conformation polymorphism analysis for heterozygous carrier detection. Am J Hum Genet 1991, 49:668-673.

15. Miyamoto K, Kesterson RA, Yamamoto H, Taketani Y, Nishiwaki E, Tatsumi S, Inoue Y, Morita K, Takeda E, Pike JW: Structural organization of the human vitamin $D$ receptor chromosomal gene and its promoter. Mol Endocrinol 1997, I I:I I65-I I79.

16. Arai H, Miyamoto K, Taketani Y, Yamamoto H, lemori Y, Morita K, Tonai T, Nishisho T, Mori S, Takeda E: A vitamin D receptor gene polymorphism in the translation initiation codon: effect on protein activity and relation to bone mineral density in Japanese women. J Bone Miner Res 1997, 12:915-921.

17. Taylor JA, Hirvonen A, Watson M, Pittman G, Mohler JL, Bell DA: Association of prostate cancer with vitamin $D$ receptor gene polymorphism. Cancer Res 1996, 56:4108-4II0.

18. Ingles SA, Ross RK, Yu MC, Irvine RA, La Pera G, Haile RW, Coetzee $\mathrm{GA}$ : Association of prostate cancer risk with genetic polymorphisms in vitamin $D$ receptor and androgen receptor. J Natl Cancer Inst (Bethesda) 1997, 89:166-170.

19. Xu Y, Shibata A, McNeal JE, Stamey TA, Feldman D, Peehl DM: Vitamin $D$ receptor start codon polymorphism (Fokl) and prostate cancer progression. Cancer Epidemiol Biomarkers Prev 2003, 1 2:23-27.

20. Habuchi T, Suzuki T, Sasaki R, Wang L, Sato K, Satoh S, Akao T, Tsuchiya N, Shimoda N, Wada Y, Koizumi A, Chihara J, Ogawa O, Kato T: Association of vitamin $D$ receptor gene polymorphism with prostate cancer and benign prostatic hyperplasia in a Japanese population. Cancer Res 2000, 60:305-308.

21. Cheteri MB, Stanford JL, Friedrichsen DM, Peters MA, Iwasaki L, Langlois $M C$, Feng $Z$, Ostrander EA: Vitamin $D$ receptor gene polymorphisms and prostate cancer risk. Prostate 2004, 59:409-4I8.

22. Medeiros R, Morais A, Vasconcelos A, Costa S, Pinto D, Oliveira J, Lopes $C$ : The role of vitamin $D$ receptor gene polymorphisms in the susceptibility to prostate cancer of a southern European population. J Hum Genet 2002, 47:4I3-4I8.

23. John EM, Schwartz GG, Koo J, Den Berg, Ingles SA: Sun Exposure, Vitamin D Receptor Gene Polymorphisms, and Risk of Advanced Prostate Cancer. Cancer Res 2005, 65:5470-5479.

24. Patiyan A, Eberhard V, Peter S: Androgen receptor and vitamin $D$ receptor gene polymorphisms and prostate cancer risk. Eur J Cancer 2006, 42:2833-2837.

25. Oakley-Girvan I, Feldman D, Eccleshall TR, Gallagher RP, Wu AH, Kolonel LN, Halpern J, Balise RP, West DW, Paffenbarger Jr, Whittemore AS: Risk of early-onset prostate cancer in relation to germ line polymorphisms of the vitamin D receptor. Cancer Epidemiol Biomarkers Prev 2004, 13:1325-1330.

26. Correa-Cerro L, Berthon P, Haussler J, Bochum S, Drelon E, Mangin $P$, Fournier G, Paiss T, Cussenot O, Vogel W: Vitamin D receptor 
polymorphisms as markers in prostate cancer. Hum Genet 1999, 105:28I-287.

27. Cicek MS, Liu X, Schumacher FR, Casey G, Witte JS: Vitamin D Receptor Genotypes/Haplotypes and Prostate Cancer Risk. Cancer Epidemiol Biomarkers Prev 2006, 15:2549-2552.

28. Ingles SA, Coetzee GA, Ross RK, Henderson BE, Kolonel LN, Crocitto L, Wang W, Haile RW: Association of prostate cancer with vitamin $D$ receptor haplotype in African-Americans. Cancer Res 1998, 58:1620-1623.

29. Hayes VM, Severi G, Padilla EJ, Eggleton SA, Southey MC, Sutherland RL, Hopper JL, Giles GG: Genetic variants in the vitamin D receptor gene and prostate cancer risk. Cancer Epidemiol Biomarkers Prev 2005, 1 4:997-999.

30. Berndt SI, Dodson JL, Huang WY, Nicodemus KK: A systematic review of vitamin $D$ receptor gene polymorphisms and prostate cancer risk. J Urol 2006, I75:1613-1623.

31. Yang Y, Wang S, Ye Z, Yang W: Association of single nucleotide polymorphism of vitamin $D$ receptor gene start codon and the susceptibility to prostate cancer in the Han nationality in Hubei area. Zhonghua Nan Ke Xue 2004, I0:4I I-4I4.

32. Liu JH, Li HW, Wang JQ, Li M, Xin DQ, Na X, Zhang M, Ye SY, Na $Y Q$ : Vitamin $D$ receptor gene Bsml polymorphism and the susceptibility to prostate cancer in northern Chinese Han population. Zhonghua Nan Ke Xue 2003, 9:413-416.

33. Chokkalingam AP, McGlynn KA, Gao YT, Pollak M, Deng J, Sesterhenn IA, Mostofi FK, Fraumeni JF Jr, Hsing AW: Vitamin D receptor gene polymorphisms, insulin-like growth factors, and prostate cancer risk: a population-based case-control study in China. Cancer Res 200I, 61:4333-4336.

34. Gleason DF, Mellinger GT: Prediction of prognosis for prostatic adenocarcinoma by combined histologic grading and clinical staging. J Urol 1974, I I I:58-64.

35. Shi YY, He L: SHEsis, a powerful software platform for analyses of linkage disequilibrium, haplotype construction, and genetic association at polymorphism loci. Cell Res 2005, 15:97-98.

36. Huang SP, Chou YH, Wayne Chang, Wu MT, Chen YY, Yu CC, Wu TT, Lee YH, Huang JK, Wu WJ, Huang CH: Association between vitamin $D$ receptor gene polymorphisms and prostate cancer risk in a Taiwanese population. Cancer Lett 2004, 207:69-77.

37. Ma J, Stampfer MJ, Gann PH, Hough HL, Giovannucci E, Kelsey KT, Hennekens $\mathrm{CH}$, Hunter DJ: Vitamin D receptor polymorphisms, circulating vitamin D metabolites and risk of prostate cancer in United States physicians. Cancer Epidemiol Biomark Prev 1998, 7:385-390.

38. Morrison NA, Yeoman R, Kelly PJ, Eisman J: Contribution of transacting factor alleles to normal physiological variability: vitamin D receptor gene polymorphisms and circulating osteocalcin. Proc Nail Acad Sci USA 1992, 89:6665-6669.

\section{Pre-publication history}

The pre-publication history for this paper can be accessed here:

http://www.biomedcentral.com/1471-2350/10/125/pre pub
Publish with Bio Med Central and every scientist can read your work free of charge

"BioMed Central will be the most significant development for disseminating the results of biomedical research in our lifetime. "

Sir Paul Nurse, Cancer Research UK

Your research papers will be:

- available free of charge to the entire biomedical community

- peer reviewed and published immediately upon acceptance

- cited in PubMed and archived on PubMed Central

- yours - you keep the copyright
BioMedcentral 